\title{
EFFECTS OF STOCK MARKET FLUCTUATIONS ON THE ADEQUACY OF RETIREMENT WEALTH ACCUMULATION
}

\author{
Eric M. Engen* \\ William G. Gale \\ Cori E. Uccello \\ CRR WP 2004-16 \\ Released: May 2004 \\ Draft Submitted: April 2004 \\ Center for Retirement Research at Boston College \\ 550 Fulton Hall \\ 140 Commonwealth Ave. \\ Chestnut Hill, MA 02467 \\ Tel: 617-552-1762 Fax: 617-552-1750 \\ http://www.bc.edu/crr
}

*Eric M. Engen is a residential scholar at the American Enterprise Institute. William G. Gale is The Arjay and Frances Fearing Miller Chair and a Senior Fellow in Economic Studies at The Brookings Institution. Cori E. Uccello is a consultant for the Urban Institute. The research reported herein was performed pursuant to a grant from the U.S. Social Security Administration (SSA) to the Center for Retirement Research at Boston College (CRR). The opinions and conclusions are solely those of the authors and should not be construed as representing the opinions or policy of the SSA or any agency of the Federal Government or of the CRR. The authors would like to thank Emil Apostolov, Ben Harris, Brennan Kelly, Samara Potter, and Emily Tang for outstanding research assistance.

(C) 2004, by Eric M. Engen, William G. Gale, and Cori E. Uccello. All rights reserved. Short sections of text, not to exceed two paragraphs, may be quoted without explicit permission provided that full credit, including (C) notice, is given to the source. 


\section{About the Center for Retirement Research}

The Center for Retirement Research at Boston College, part of a consortium that includes parallel centers at the University of Michigan and the National Bureau of Economic Research, was established in 1998 through a grant from the Social Security Administration. The goals of the Center are to promote research on retirement issues, to transmit new findings to the policy community and the public, to help train new scholars, and to broaden access to valuable data sources. Through these initiatives, the Center hopes to forge a strong link between the academic and policy communities around an issue of critical importance to the nation's future.

\section{Center for Retirement Research at Boston College}

550 Fulton Hall

140 Commonwealth Ave.

Chestnut Hill, MA 02467

phone: 617-552-1762 fax: 617-552-1750

e-mail: crr@bc.edu

http://www.bc.edu/crr

Affiliated Institutions:

American Enterprise Institute

The Brookings Institution

Massachusetts Institute of Technology

Syracuse University

Urban Institute 


\begin{abstract}
This paper examines the relation between fluctuations in the aggregate value of equities and the adequacy of households' saving for retirement. We find that many and perhaps most households appear to be saving adequate amounts for retirement, but almost no link between stock values and the adequacy of retirement saving. Historical variation in equity values and ownership correlates poorly with historical variation in the adequacy of saving. Even a simulated 40 percent decline in stocks has little effect on the adequacy of saving. The results occur because equities are concentrated among households with significant amounts of other wealth.
\end{abstract}


Several secular trends have led policymakers and researchers to question the adequacy of households' financial preparations for retirement in recent years. The baby boom generation -which has been large enough to shape societal trends at every life-cycle stage it moves through -is rapidly approaching retirement. The need for retirement saving has increased as retirement ages have held constant or fallen, but life-spans have increased. Social security and medicare face long-term shortfalls that may require benefit cuts. Family networks, a traditional source of support in old age, are suspected to provide less support in the future. Private pension coverage has stagnated. Saving rates have hovered near zero and many households approach retirement with little in the way of financial assets.

On the other hand, the last two decades have seen a strong increase in equity values and in the share of households with direct and indirect ownership of equities. Equity values rose 50 percent relative to GDP from 1981 to 1990, and then tripled relative to GDP between 1990 and 1999. The dramatic, sustained rise in stock market values helped assuage some of the concerns about the adequacy of saving, but the decline since 2000 has led to renewed concerns about saving adequacy.

This paper examines the adequacy of households' saving for retirement and makes two contributions relative to the previous literature. ${ }^{1}$ First, using data from the 2001 Survey of Consumer Finances, we update previous work and provide more recent evidence on how well households are preparing for retirement. In contrast, most previous work uses data that is now 10 years old or older. The use of more recent data is particularly useful in light of the significant changes in the composition and level of wealth accumulation in the 1990s.

To determine whether households are saving adequately, we compare actual wealth

\footnotetext{
${ }^{1}$ For reviews of the literature, see Engen, Gale, Uccello (1999) and Congressional Budget Office (2003).
} 
accumulation to saving patterns generated by a stochastic life-cycle model that explicitly recognizes precautionary savings due to uncertain earnings and mortality. The incorporation of uncertainty has an important impact on the interpretation of data on wealth accumulation, since optimal wealth accumulation patterns will vary widely across households depending on the household-specific path of earnings realizations. Our second contribution relative to other work is to examine explicitly the role of the stock market in determining the adequacy of households' financial preparation for retirement.

Despite the common, popular connection between these items, there has been no systematic analysis linking these two issues. Although it may seem obvious that increases in the stock market help people save more for retirement, the overall effect on the adequacy of saving may be more complex. First, households may adjust their other wealth in response to stock market fluctuations. That is, they may choose to consume a significant amount of increases in equity values before retirement, rather than in retirement. Second, they may choose to retire earlier. Third, to the extent that stock holdings are concentrated among households that are extremely wealthy, variations in equity values will have little effect on how well the vast majority of households are faring with respect to retirement saving.

Our central findings are contrary to what might be considered the common view in two ways. Despite the trends noted above, we find that many and perhaps most households appear to be saving adequate amounts for retirement. Despite the popular linking of equity values and retirement saving, we find almost no link between variations in stock values and variations in the overall level or distribution of adequate saving. We derive conclusions regarding the stock market in two ways. We show that historical variation in equity values and ownership does not correlate well with historical variation in the adequacy of saving. We also show that a 40 percent 
decline in stock values -- roughly the decline of broad market indices from their peak in 2000 to their trough in 2002 -- has little effect on the observed adequacy of saving.

The main reason equity price fluctuations have such a small effect on the observed adequacy of saving is that most households who hold stocks have significant amounts of other wealth and thus are deemed to be saving adequately even if their stock values fall. Despite the large increase over time in the share of households that hold some equities, the vast majority of American households hold very little equity or none at all, so that even substantial variation in equity prices has little direct effect on the wealth of most American households. These findings, however, do not in any way suggest that variations in aggregate equity values are unimportant factors in overall economic performance or aggregate capital accumulation.

The next two sections describe the underlying simulation model and the data we employ. Section III updates our earlier analysis of the adequacy of saving to incorporate data from 1998 and 2001. The following two sections provide information on the growth of equity values and ownership over the past 20 years, and analyze the effects of equity values on the adequacy of saving. Section VI concludes.

\section{A Stochastic Model of Optimal Saving}

\section{A. Description $^{2}$}

Households enter the model with two adults aged 21. One child is added at age 25 and a second at age 28. Each child leaves the home at age 21. Families are not linked across generations. Each adult faces an age-varying probability of dying, with a maximum life span of 110 years. Each year, the assets of those who die are bequeathed to members of the generation

\footnotetext{
${ }^{2}$ Engen, Gale, and Uccello (1999) provide a complete description of the model and citations to related literature.
} 
that is then 45 years old. The bequests are distributed in accordance with the wealth distribution of the 45-year-olds, thus capturing the empirically established tendency of wealthier households to receive larger inheritances. The inheritance is assumed to be unanticipated.

In each period, forward-looking households maximize expected lifetime utility by choosing total consumption (consumption per capita times the number of people in the household) and total saving subject to a lifetime budget constraint, nonnegativity constraints on net assets, income and payroll taxes, and uncertainty regarding future earnings, life span, and inheritances. There are no markets for insurance against these uncertainties. Because there is a positive probability of death at each age, borrowing against the uncertain portion of future income and inheritances is not permitted.

Utility is separable over time, and separable within a time period between consumption and leisure. The utility function for consumption exhibits constant relative risk aversion, a constant intertemporal elasticity of substitution, and constant prudence, which implies that risky income and uncertain life spans lead to precautionary saving. Thus, households save for retirement and as a precaution against downturns in future income and the possibility of outliving assets once retired.

Before retirement, consumption may be financed by labor earnings, decumulations of previously accumulated assets, or inheritances received. After retirement, consumption is financed by assets accumulated earlier, which are fully taxable, and by annuity income from social security and private DB pensions. Labor supply is exogenous and retirement occurs at a predetermined age. Household earnings are modeled as the sum of a stochastic component and a non-stochastic component. The latter follows a hump-shaped pattern with respect to age and varies by education class. 
We use a numerical solution method to solve households' consumption-saving problem. Earnings shocks over the life cycle are simulated with a random number generator for each of 10,000 households. Because households receive different earnings shocks, they end up with different realized income, consumption, saving, and wealth.

The model requires specification of numerous parameter values. Conditional survival probabilities for males and females are based on estimates from the life tables for 1994 used by the Social Security Administration (1997). Retirement occurs at age 62. The real after-tax rate of return is set at 3 percent, an average of the historical real risk-free rate of return and a mix of all returns (the average tax rate on capital income is used here). ${ }^{3}$ We set the coefficient of relative risk aversion at 3, which implies an intertemporal elasticity of substitution of 0.33 .

To estimate the mean age-earnings profile, we use panel data on earnings of employed heads of households and their spouses from the Panel Survey of Income Dynamics, conducted by the University of Michigan's Institute for Social Research, from 1980 to 1992. We exclude the self-employed and households where the head is over 65 years old. We estimate a fixed-effects model with log earnings as a function of age, age squared, and year dummies to control for macroeconomic effects, with separate equations for household heads with 16 or more years of education and those with less education. Earnings for the group with more education are always higher, rise and fall more steeply, and peak at later ages than for the group with less education. In addition, the wages of all age groups are assumed to rise by 1 percent per year to reflect aggregate growth in the economy.

\footnotetext{
${ }^{3}$ If the model had a safe asset and risky assets, the Euler equation for optimal consumption growth would be determined by the return on the safe asset, and the overall return on saving would be a weighted average of these assets. The real return on short-term Treasury bills has averaged about 1 percent historically. Longer-term government and corporate bonds have yielded about 2 percent in real terms, and the equity market about 9 percent in the postwar period. A market-weighted basket of these returns gives a real pre-tax return of about 5 percent.
} 
To measure the variability in current earnings, we use data from the Internal Revenue Service-Michigan tax panel to estimate the stochastic process for the logarithm of earnings variations (Engen 1993). Measurement error is less of a problem with earnings data collected from Internal Revenue Service W-2 forms filed with income tax returns, because wages are directly reported by employers. Based on that analysis, we model labor earnings shocks as a first-order autoregressive process with a persistence parameter of 0.85 and a variance of 0.05 . Under this specification, about half of a given shock to earnings remains after five years.

We impose a progressive income tax, similar to the U.S. system in 1998, with statutory marginal rates of 15 percent, 28 percent, 31 percent, 36 percent, and 39.6 percent. The taxable income brackets, in dollars, are those effective in 1998 for joint tax filers. Households are allowed a standard deduction of $\$ 7,100$ and an exemption of $\$ 2,650$ for each person. To capture in a simple way the effect of preferential capital gains tax rates and tax-preferred saving vehicles, tax rates on capital income are capped at 20 percent. The payroll tax is imposed at a 6.2 percent rate--the employee share--up to the 1998 earnings limit of $\$ 68,400$.

We assume each household receives income from social security and defined benefit plans based on features of the average age-earnings profile of its education class, not on its individual wage profile. For example, among households without a pension, social security is assumed to replace 35 percent of average final earnings for those with less than sixteen years of education, and 21 percent of average final earnings for those with sixteen years or more of education. For households with both pensions and social security, the replacement rates of the two combined are 64 percent and 57 percent of final earnings for the two education groups, respectively. Real private DB pension benefits are assumed to decline by 1 percent per year. 
Specifying the appropriate time preference rate is difficult but crucial. The goal of the model is to describe optimal (and, implicitly, time-consistent) behavior, rather than actual behavior. As a result, choosing the rate so that the model is well calibrated with household wealth data, or using estimates of time preference rates from previous empirical studies, would inappropriately impose the assumption that households' actual behavior was optimal. Basing the choice on time preference rates used in other simulation models would also be misleading, since most of these models aim to explain actual behavior. We use the after-tax rate of interest (3 percent) as our base case. Engen, Gale, and Uccello (1999) also report results with a time preference rate of zero.

\section{B. Optimal Saving}

The model implicitly defines a household to be saving adequately if it is accumulating enough wealth to be able to smooth its marginal utility of consumption over time in accordance with the optimizing model of consumption described above.

We report simulation and empirical results in terms of the ratio of current wealth to current earnings. ${ }^{4}$ Optimal wealth-earnings ratios will evolve differently for different households for two reasons. The first is that differences in education affect the level and shape of the ageearnings profile and differences in pension coverage affect retirement income. Table 1 reports median optimal wealth-earnings ratios for households classified by age, education, and pension status. Optimal wealth-earnings ratios rise over the life cycle. Controlling for education, households with pensions have lower optimal wealth-earnings ratios than those without, because

\footnotetext{
${ }^{4}$ Despite our reporting the results this way, our model should not be confused with a "buffer stock" or target saving model (see Carroll, 1992). In our model, as already noted, households save both for retirement and as a precaution against uncertain income and life span. The model generates consumption-age profiles that rise, peak in the mid$50 \mathrm{~s}$, and then decline, controlling for family size. Because of the need for precautionary saving, generated by uncertain earnings, the general shape of the consumption-age profile is invariant with respect to whether the time preference rate is above or below the after-tax rate of return.
} 
pensions provide retirement income. Controlling for pension status, college graduates have lower optimal wealth-earnings ratios when young and almost equal or higher ratios when old than do other households.

The second reason why wealth-earnings ratios vary across households is that households receive different earnings shocks over time and at a given point in time. As a result, households that are observationally equivalent in the data - that is, that are identical with respect to age, current earnings, family size, life expectancy, education, and pension status-will have different optimal wealth-earnings ratios. Table 2 shows the importance of heterogeneous earnings shocks in generating a distribution of optimal wealth-earnings ratios. The table focuses on college graduates with pensions, but similar results occur for other groups (Engen, Gale, Uccello 1999). Optimal wealth-earnings ratios among 35 to 39 year olds vary by a factor of 100 , from 0.01 at the 5 th percentile to 1.02 at the 95 th percentile. Among 60 to 62 year olds, optimal wealthearnings ratios vary by a factor of almost 20 .

Notably, these observed ratios represent households' optimal responses to the pattern of earnings shocks they receive. The low wealth accumulation exhibited by a significant minority of households in the simulation model is consistent with optimizing behavior and in no way implies a retirement saving shortfall owing to myopia, irrationality, or poor information.

\section{Data issues}

We use data from the 1983, 1989, 1992, 1995, 1998, and 2001 Surveys of Consumer Finances (SCFs). The SCF is undertaken by the Federal Reserve Board with the cooperation of the Department of the Treasury. The survey oversamples high-income households and is designed to provide detailed information on family balance sheets, pension status, income, and 
demographics. We use data for married households where the husband is between the ages of twenty-five and sixty-two and works at least twenty hours per week. This generates sample sizes between 1,300 and 1,900 in each year. ${ }^{5}$ All of our results are weighted in accordance with a nationally representative population. It is worth keeping in mind throughout the discussion of the empirical results that some of the sample sizes are small. Appendix table 1 reports sample size by age, education, and pension status for the 2001 sample.

Because the simulation model accounts for precautionary and retirement saving, the empirical wealth measure needs to be broad enough to account for both. We define three measures of wealth. We define broad wealth as all net worth other than equity in vehicles. Specifically, broad wealth is the sum of equity in the primary residence, other real estate equity, equity in businesses, and net financial assets. Financial assets include balances in DC plans, 401(k) plans, Individual Retirement Accounts, and Keogh plans as well as non-tax-advantaged financial assets, less consumer debt. Narrow wealth is broad wealth less all equity in the primary residence. Intermediate wealth is broad wealth less half of equity in the primary residence.

For reasons explained in Engen, Gale, and Uccello (1999), we believe it is appropriate to include housing equity in retirement saving calculations. Nevertheless, it may not be appropriate to include every dollar of equity, since liquidating housing wealth through sale or reverse mortgages imposes some transactions costs. Excluding half of housing wealth—as we do with our intermediate wealth measure—-to account for transactions costs certainly overestimates such costs. Therefore, we believe that our intermediate wealth measures generate reasonable and

\footnotetext{
${ }^{5}$ For discussions of the SCF see Aizcorbe, et al (2003), Avery et al (1984a, b), Avery and Elliehausen (1986), Kennickell and Shack-Marquez (1992), Kennickell and Starr-McCluer (1994), Kennickell, et al (1997), and Kennickell et al (2000). We use the first replicate of each observation in the SCF.
} 
probably conservative empirical results. Nevertheless, we present many of the results for all three wealth measures, which together bound all the possible effects of including housing equity.

Households in which at least one adult has a DB pension from his or her current job are assumed to receive pension benefits, and their wealth, excluding DB pensions and social security, is compared with the simulation benchmarks developed above for households with pension coverage. In effect, this treatment provides each household that has a DB pension from the current job with average DB pension benefits, conditional on education status, as shown in table 1.6

Focusing the sample on married couples where the husband is still a full-time worker may somewhat bias the sample over time, since wealthier households may retire earlier. As reported in Engen, Gale, and Uccello (1999), this may affect the observations for 61- and 62-year olds, but is less likely to have a significant effect on younger age groups.

\section{Recent Evidence on the Adequacy of Saving}

Most previous studies are based on data that is now at least a decade old. Our own previous results in Engen, Gale, and Uccello (1999) extend only through 1995. But as noted above the latter half of the 1990s saw significant changes in the level and composition of wealth and in other factors, so examination of more recent trends should provide useful information. This section updates our earlier estimates of the adequacy of saving to include analysis of data from the 2001 SCF.

For a household with a given set of observable characteristics, the simulation model generates a distribution of optimal wealth-earnings ratios, rather than a single optimal level. This

\footnotetext{
${ }^{6}$ We somewhat underestimate DB pension coverage for SCF households because households with DB plans from prior jobs but not on the current job are treated as not having DB plan coverage.
} 
implies that we cannot determine precisely the optimal wealth-earnings ratio for any particular household. Instead, we compare the distributions of observed and simulated wealth-earnings data for married households with a given set of characteristics: age, lifetime earnings, education, and pension status. Thus, our strategy for examining the adequacy of saving focuses mainly on two issues: determining the proportion of households whose wealth-earnings ratios exceed the median simulated wealth-earnings ratio for households with the same characteristics; and comparing wealth-earnings ratios at different percentiles of the actual and simulated distributions. Both approaches provide valuable information, but neither permits us to identify which particular households are saving adequately or inadequately. ${ }^{7}$

\section{A. Median Wealth-Earnings Ratios}

Table 3 reports the results of comparing, for each married couple in the 2001 SCF where the husband works full-time and is between ages 25 and 62, the couple's actual wealth-earnings ratio and the median of the distribution of wealth-earnings ratios from the simulation for households with the same characteristics. For the full sample, the Table shows that 61 percent of households have ratios of intermediate wealth to earnings that exceed the median simulated wealth-earnings ratio for households with the same observable characteristics.

The interpretation of this result depends on the fact that the saving benchmark is derived from a stochastic rather than a nonstochastic model. In a nonstochastic model, all households of the same age, earnings patterns, education, and pension status would be assigned the same optimal wealth-earnings ratio, and the finding above would be interpreted as showing that 61 percent of households exceed the optimal ratio. That would mean that 39 percent of households

\footnotetext{
${ }^{7}$ As discussed below, recent work by Scholz, Seshadri and Khitatrakun (2003) estimates optimal wealth measures on an individual basis.
} 
fall short of their assigned optimal wealth-earnings ratio. This would (perhaps erroneously) suggest that a significant portion of the population is undersaving.

In contrast, once it is recognized that households face uncertainty about their future earnings, it is appropriate to use a stochastic model as the benchmark. This in turn implies that one would expect only 50 percent of households to exceed the median wealth-earnings ratio. Thus, the same fact—that 61 percent of actual households exceed the simulated median—would instead suggest adequate, indeed somewhat more than adequate, amounts of wealth accumulation relative to the benchmark at the median of the distribution.

Table 3 also shows that the treatment of housing wealth can have significant effects on the results, with 52 percent and 69 percent of households having wealth-earnings ratios that exceed the median simulated ratio when housing is entirely excluded or entirely included, respectively. We emphasize that all of these results should be compared against a benchmark expectation that only 50 percent of households will exceed the median.

The table shows several other interesting results as well. Controlling for education, having a pension is associated with an increase of about 7 percentage points in the proportion of households that exceed the median target wealth-earnings ratio. Controlling for defined benefit pension coverage, having more education is associated with an increase of between 22 and 31 percentage points in the likelihood of exceeding the simulated median wealth-earnings ratio. These qualitative results are consistent with those of numerous previous studies. ${ }^{8}$ As with previous studies of the adequacy of saving, we do not determine whether the results are due to

\footnotetext{
${ }^{8}$ See Banks, Blundell, and Tanner (1998); Bernheim (1992); Bernheim and Scholz (1993); Gale (1997); Kotlikoff, Spivak, and Summers (1982); Mitchell, Moore, and Phillips (1998); Moore and Mitchell (1997); Robb and Burbidge (1989); Warshawsky and Ameriks (1998).
} 
the direct effects of pensions and education or to unobserved characteristics that affect household saving and are correlated with pension coverage and education.

The proportion of households whose wealth exceeds the optimal median target falls somewhat as age rises, and rises sharply as income rises (other than the group with income below $\$ 10,000$, which may be unrepresentative since the sample is intended to be full-time workers). This suggests that high-earnings households may have some important differences in tastes or opportunities for saving compared with others. ${ }^{9}$ These are similar to patterns found in the 1992 SCF in Engen, Gale, and Uccello (1999).

\section{B. Distribution of Wealth-Earnings Ratios}

Table 4 provides evidence on the distribution of wealth-earnings ratios. The top panel reports data from the $2001 \mathrm{SCF}$ using the narrow wealth measure. The bottom panel provides simulated wealth-earnings ratios from the model, using the same distribution of households across education groups as is found in the HRS.

The median wealth-earnings ratio in the data exceeds the median in the simulation for intermediate and broad wealth measures. In addition, the model underestimates wealth-earnings ratios at the high end of the distribution. That is, there is a significant amount of real-world wealth accumulation that the model does not include. This may not be particularly surprising because the model does not include bequest motives or the possibility of receiving a very high rate of return, perhaps on an entrepreneurial investment.

At the 25th percentile and lower, however, the empirical wealth-earnings ratio is below that of the simulated distribution and the difference is especially large at the 5 th percentile. This is consistent with a significant amount of undersaving at the low end of the wealth distribution.

\footnotetext{
${ }^{9}$ For further evidence on how saving rates vary by income, see Carroll (2000); Dynan, Skinner, and Zeldes (2003); Engen, Gale, and Uccello (1999, 2004), and Gentry and Hubbard (1998).
} 
It is also consistent, however, with other explanations that the model does not take into account. In particular, the model omits any sort of government-provided consumption floor (Hubbard, Skinner, Zeldes 1995, Scholz, Seshadri, Khitatrakun 2003).

\section{The Growth and Distribution of Equities}

We now turn to examine the role of the stock market in the adequacy of saving. This section provides background on the evolution of equity values and the diffusion of equity ownership. The next section provides tests of the impact of these changes on the adequacy of wealth.

Figure 1 shows the ratio of equity values to GDP and to overall net worth annually since 1960. After peaking at about 100 percent of GDP in the late 1960s, the stock market declined sharply to 38 percent of GDP in 1974 and then remained at about 50 percent or less of GDP for almost a decade. It rose to 60 percent of GDP in the late 1980s, and 85 percent of GDP by 1993 before skyrocketing to more than 185 percent of GDP in 1999. Aggregate equity values then fell sharply to less than 100 percent of GDP in 2002 before rising in 2003.

The general rise in equity values over the past 20 years coincided with a gradual and significant increase in the share of households holding equities. ${ }^{10}$ Nevertheless, even by 2001 , equity holdings were concentrated among a minority of older, wealthier households. As shown in Table 5, in the sample we employ, 83 percent of equities are held by households in the highest wealth quintile and another 12 percent is held by the second highest quintile.

The second panel of Table 5 shows that median equity holdings among households that

\footnotetext{
${ }^{10}$ Poterba and Samwick (1995) provide detailed information on these trends. See also Aizcorbe, et al (2003), Avery et al (1984a, b), Avery and Elliehausen (1986), Kennickell and Shack-Marquez (1992), Kennickell and StarrMcCluer (1994), Kennickell, et al (1997), and Kennickell et al (2000).
} 
hold equities. In the bottom three quintiles, the median equity holdings are quite small. One way to gauge the magnitude of stock holdings is to examine the effect on retirement income of a 40 percent decline in equity values. In the second quintile, for example, the median equity holding is $\$ 6,500$. A 40 percent decline would reduce this to $\$ 3,900$. At an annuity rate of 7 percent, the resulting decline in retirement income would be less than $\$ 200$ per year. The third panel shows mean equity holdings among households with equities. Again, the figures are small for the bottom three quintiles.

Table 5 thus provides the essential intuition for the more formal results in the subsequent section. Because most stocks are held by households with substantial wealth, and most households hold very little equity, fluctuations in stock market values can affect aggregate wealth, yet have little effect on households' ability to save adequately for retirement.

\section{Effects of stock market fluctuations on the adequacy of saving}

We present two sets of tests of the impact of the stock market on the adequacy of wealth accumulation. The first test examines how the adequacy of saving has changed over time. As noted in the previous section, equity values and ownership have changed significantly over time. Thus, if stock market fluctuations have a significant effect on the adequacy of saving, the relations between actual and optimal median wealth-earnings ratios and the actual and optimal distribution of wealth-earnings ratios should have changed over time as well. The second test returns to the 2001 data, and simulates the effects of a stock market decline of 40 percent. Again, if stock market fluctuations affect the adequacy of saving, the relation between actual wealth-earnings ratios and simulated optimal ratios should be altered significantly. In neither case do we find a significant impact of stock market fluctuations on the adequacy of saving. 


\section{A. Effects over time}

Table 6 reports the proportion of SCF households whose wealth-earnings ratios exceeded the simulated median ratio over time. The results suggest that the stock market fluctuations (as well as other factors that changed over time) raised financial wealth. For example, the proportion of households that exceeded the median simulated wealth-earnings ratio using narrow wealth rose by almost 10 percentage points, from 43 percent in 1983 to more than 52 percent in 2001. This occurred presumably in part because of the large buildup of financial assets in general and stock market values in particular during this period.

But this increase in financial assets did not translate into increases in the adequacy of saving using broader measures of wealth. Using the intermediate wealth measure, the proportion of households who exceeded the median simulated wealth-earnings ratio for households with their characteristics fell within a very narrow range, between 58 percent and 62 percent, in every sample year between 1983 and 2001, and was virtually the same in 1983 and in 2001. Using the broad wealth measure, the comparable share ranged between 66 percent and 71 percent and was actually lower in 2001 than in 1983.

These results indicate that different measures of the adequacy of saving can move in different directions over the same time period. They are also consistent with the view that dramatic changes in equity values have had little effect on broad measures of the adequacy of saving for retirement.

Table 6 also shows how different cohorts have fared over time relative to their median simulated wealth-earnings ratios. It is worth emphasizing that some of the variation in the agespecific data may be due to relatively small sample sizes. Nevertheless, the data suggest some interesting patterns. 
Wealth accumulation for younger baby boomers (those born between 1956 and 1964) has improved relative to the simulated medians over the 1989-95 period, as they aged from a range of 25 to 33 years to between 31 and 39 years. Since 1995, their results have held constant for narrow wealth, but fallen for intermediate and broad wealth.

For older boomers (those born between 1946 and 1955), the adequacy of wealth accumulation has declined relatively consistently as the cohort has aged. Even so, the share of such households who exceeded their median simulated wealth-earnings ratio was 54 percent for intermediate wealth and 68 percent using broad wealth in 2001.

These results show that trends in wealth accumulation can vary significantly across cohorts. This is not consistent with a view that stock market forces are driving factors in determining wealth accumulation, since the market changes in the same way for all cohorts at the same time.

Table 7 shows the evolution of the distribution of wealth-earnings ratios over time. The key results here are that the wealth-earnings ratio at the $95^{\text {th }}$ percentile of the distribution is smaller in 1995 than in 1992 and is the same in 1998 as in 1992, despite the market being substantially higher in 1995 and especially 1998 than in 1992. Again, the data do not appear to change in conformity with changes in equity values.

\section{B. Simulating a stock market decline}

Table 8 examines the effects of simulated stock market declines on the share of households whose actual wealth would exceed the median optimal wealth-earnings ratios. We simulate a stock market decline by assuming that all equities, including those in retirement accounts, fall in value by 40 percent.

Table 8 shows that even a decline of this magnitude has a negligible impact on the share 
of households whose wealth-earnings ratios exceed the median target. Using narrow, intermediate, and broad wealth, the share of households whose wealth-earnings ratios exceed the median target falls by 4, 2 and 2 percentage points, respectively. Almost all of the changes in particular demographic groups are also small.

The result is not very sensitive to the underlying value of the stock market. In 1992, a 40 percent decline in stock market wealth reduced the share of households with wealth-earnings ratios above the simulated median by 0.8 percentage points for broad wealth and 1.5 percentage points for intermediate wealth (Engen, Gale, and Uccello 1999).

Using data from the 1998 SCF (not shown), which was conducted at a time when the aggregate stock market was substantially higher than in 1992, a 40 percent decline had roughly the same effect, reducing the share of households with wealth-earnings ratios above the simulated median by 0.8 percentage points for broad wealth and 1.1 percentage points for intermediate wealth.

One possible explanation for the small impact of large stock market declines on the share of households whose actual wealth-earnings ratio exceeds the simulated median is that share is simply not very sensitive to any changes. Engen, Gale, and Uccello (1999), however, show that the share can be moved by other policies or exogenous shocks, at least in earlier years. Table 9 shows similar effects using the 2001 data. All of the following changes have bigger effects on the measured adequacy of saving than does a 40 percent decline in the stock market: exclusion of business wealth, a 20 percent increase in expected consumption needs (perhaps due to medical expenditures) in retirement, or a10 percent decline in mortality risk.

A more likely explanation is simply that despite the growth of the stock market and the growth in the share of households that own stocks, directly or indirectly, stock ownership 
remains heavily concentrated among households that were already saving more than enough for retirement.

\section{Conclusion}

We find that many and perhaps most married couples, where the husband is working fulltime, are saving adequately for retirement and that fluctuations in the aggregate stock market values have little impact on the observed adequacy of saving. Our analysis explicitly incorporates uncertainty into the analysis of the adequacy of saving, a departure from most previous work and one that has crucial implications for how empirical patterns are interpreted. An important caveat to our results is that we compare the distributions of observed and simulated wealth outcomes, but can not derive optimal wealth values for individual households. In contrast, Scholz, Seshadri, and Khitatrakun (2003) solve for optimal wealth accumulation for each household, using a model that recognizes uncertainty relating to earnings, mortality and health expenditures. In all important respects, their results are similar to those reported here and in Engen, Gale, and Uccello (1999). In particular, they find that most households are saving at least as much as the underlying simulation model indicates is optimal, and that there is undersaving among the 20 percent of households at the low-end of the wealth distribution. This suggests that incorporating household-specific targets strengthens the support for the conclusions obtained above.

A second caveat is that we do not examine the adequacy of saving among singles, widows, or married couples where the husband is unemployed. These groups are likely to have lower rates of wealth accumulation than the sample we examine. As a consequence, our results should not be interpreted as necessarily applying to the whole population. 


\section{References}

Aizcorbe, Ana M., Arthur B. Kennickell, and Kevin B. Moore. 2003. "Recent Changes in U.S. Family Finances: Results from the 1998 and 2001 Survey of Consumer Finances." Federal Reserve Bulletin 89(1): 1-32 (January).

Avery, Robert B., Gregory E. Elliehausen, and Glenn B. Canner. 1984. "Survey of Consumer Finances, 1983." Federal Reserve Bulletin 70(9): 679-692 (September).

Avery, Robert B., Gregory E. Elliehausen, and Glenn B. Canner. 1984. "Survey of Consumer Finances, 1983: A Second Report" Federal Reserve Bulletin 70(12): 857-868 (December).

Avery, Robert B. and Gregory E. Elliehausen. 1986. "Financial Characteristics of High-Income Families.” Federal Reserve Bulletin 72(3): 163-177 (March).

Banks, James, Richard Blundell, and Sarah Tanner. 1998. "Is There a Retirement-Savings Puzzle?" American Economic Review 88(4): 769-88.

Bernheim, B. Douglas. 1992. "Is the Baby Boom Generation Preparing Adequately for Retirement? Technical Report." Unpublished paper. New York: Merrill Lynch (September).

Bernheim, B. Douglas, and John Karl Scholz. 1993. "Private Saving and Public Policy." In Tax Policy and the Economy, vol. 7, edited by James Poterba. Cambridge and London: MIT Press.

Carroll, Christopher D. 1992. "The Buffer-Stock Theory of Saving: Some Macroeconomic Evidence." Brookings Papers on Economic Activity, 2: 1992, 61-135.

Carroll, Christopher D. 2000. "Why Do the Rich Save So Much?" in Joel P. Slemrod, ed. Does Atlas Shrug? The Economic Consequences of Taxing the Rich. Forthcoming.

Congressional Budget Office. 2003. "Baby Boomers' Retirement Prospects: An Overview." November.

Dynan, Karen E., Jonathan Skinner, and Stephen P. Zeldes. 2003. "Do the Rich Save More?" August 11. Dartmouth College.

Engen, Eric M.1993. "Consumption, Uncertain Lifespan, and Euler Equations: Estimation with Panel Data." Unpublished paper. University of California, Los Angeles.

Engen, Eric M.. 1993. "Consumption and Saving in a Life-Cycle Model with Stochastic Earnings and Uncertain Lifespan." Unpublished paper. Washington: Federal Reserve Board (October).

Engen, Eric M., William G. Gale, and Cori E. Uccello. 1999. "The Adequacy of Household Saving." Brookings Papers on Economic Activity. No 2, pp. 65-187. 
Engen, Eric M., William G. Gale, and Cori E. Uccello. 2004 "Effects of Stock Market Fluctuations on the Adequacy of Households' Retirement Saving" mimeo. Brookings.

Gale, William. 1997. "Will the Baby Boom Be Ready for Retirement?” Brookings Review 15(3): 4-9 (Summer).

Gentry, William M., and R. Glenn Hubbard. 1998. "Why do the Wealthy Save so Much? Saving and Investment Decisions of Entrepreneurs." Working Paper (July).

Hubbard, R. Glenn, Jonathan Skinner, and Stephan P. Zeldes. 1995. "Precautionary Saving and Social Insurance.” Journal of Political Economy 103: 360-399.

Kennickell, Arthur B. and Janice Shack-Marquez. 1992. "Changes in Family Finances from 1983 to 1989: Evidence from the Survey of Consumer Finances.” Federal Reserve Bulletin 78(1): 1-18 (January).

Kennickell, Arthur B. and Martha Starr-McCluer. 1994. "Changes in Family Finances from 1989 to 1992: Evidence from the Survey of Consumer Finances." Federal Reserve Bulletin 80(10): 861-882 (October).

Kennickell, Arthur B., Martha Starr-McCluer, and Annika E. Sunden. 1997. "Family Finances in the U.S.: Recent Evidence from the Survey of Consumer Finances." Federal Reserve Bulletin 83(1): 1-24 (January).

Kennickell, Arthur B., Martha Starr-McCluer, and Brian J. Surette. 2000. "Recent Changes in U.S. Family Finances: Results from the 1998 Survey of Consumer Finances." Federal Reserve Bulletin 86(1): 1-29 (January).

Kotlikoff, Laurence J., Avia Spivak, and Lawrence H. Summers. 1982. "The Adequacy of Savings." American Economic Review 72(5): 1056-69 (December).

Mitchell, Olivia, James Moore, and John Phillips. 1998. "Explaining Retirement Saving Shortfalls." Pension Research Council, Philadelphia, PA.

Moore, James F., and Olivia S. Mitchell. 1997. "Projected Retirement Wealth and Savings Adequacy in the Health and Retirement Survey." NBER Working Paper 6240. Cambridge, Mass.: National Bureau of Economic Research (October).

Poterba, James M. and Andrew A. Samwick. 1995. "Stock Ownership Patterns, Stock Market Fluctuations, and Consumption." Brookings Papers on Economic Activity No 2, 295-372.

Robb, A. L., and J. B. Burbidge. 1989. “Consumption, Income, and Retirement.” Canadian Journal of Economics 22(3): 522-42 (August). 
Scholz, John Karl, Ananth Seshadri and Surachai Khitatrakun. 2003. "Are Americans Saving 'Optimally' for Retirement?' University of Wisconsin.

U.S. Social Security Administration. 1997. "Social Security Area Population Projections." Actuarial Study 112. Baltimore: Social Security Administration, Office of the Chief Actuary.

Warshawsky, Mark J., and John Ameriks. 1998. "What Does Financial Planning Software Say About Americans' Preparedness for Retirement?” TIAA-CREF Institute, New York, NY (July). 
Table 1

Median Simulated Wealth-Earnings Ratios

by Age, Education, and Pension Status

\begin{tabular}{lccccc}
\hline & \multicolumn{2}{c}{ Education $<16$ years } & & \multicolumn{2}{c}{ Education $\geq 16$ years } \\
\cline { 5 - 6 } Age & No pension & Pension & & No pension & Pension \\
\hline & & & & & \\
$30-34$ & 0.25 & 0.23 & & 0.06 & 0.06 \\
$35-39$ & 0.56 & 0.46 & & 0.20 & 0.14 \\
$40-44$ & 1.08 & 0.83 & & 0.62 & 0.35 \\
$45-49$ & 1.84 & 1.36 & & 1.39 & 0.78 \\
$50-54$ & 2.70 & 1.97 & & 2.4 & 1.39 \\
$55-59$ & 3.76 & 2.66 & & 3.67 & 2.19 \\
$60-62$ & 4.74 & 3.28 & & 4.91 & 2.92 \\
\hline
\end{tabular}

Source: Authors' estimates as described in the text. 
Table 2

Distribution of Simulated Wealth-Earnings Ratios by Age Among Households with Sixteen or More Years of Education and with Private Pensions

\begin{tabular}{lccccc}
\hline Age & $\begin{array}{c}\text { 5th } \\
\text { percentile }\end{array}$ & $\begin{array}{c}\text { 25th } \\
\text { percentile }\end{array}$ & Median & $\begin{array}{c}\text { 75th } \\
\text { percentile }\end{array}$ & $\begin{array}{c}\text { 95th } \\
\text { percentile }\end{array}$ \\
\hline $30-34$ & 0.00 & 0.02 & 0.06 & 0.17 & 0.52 \\
$35-39$ & 0.01 & 0.04 & 0.14 & 0.39 & 1.02 \\
$40-44$ & 0.01 & 0.11 & 0.35 & 0.81 & 1.82 \\
$45-49$ & 0.04 & 0.31 & 0.78 & 1.48 & 2.94 \\
$50-54$ & 0.12 & 0.69 & 1.39 & 2.35 & 4.15 \\
$55-59$ & 0.29 & 1.22 & 2.19 & 3.41 & 5.77 \\
$60-62$ & 0.37 & 1.68 & 2.92 & 4.35 & 7.05 \\
\hline
\end{tabular}

Source: Authors' estimates as described in the text. 
Table 3

Percent of Households At or Above Median Simulated Wealth-Earnings Ratio

$\underline{\text { Sample }}$

\begin{tabular}{ccc} 
Narrow & Intermediate & Broad \\
Wealth & Wealth & Wealth \\
\hline
\end{tabular}

Full Sample

52.3

61.0

68.8

Households With Pension Coverage

All

with 4 or more years of college

with less than 4 years of college

Households Without Pension Coverage

All

with 4 or more years of college

with less than 4 years of college

All Households With 4 or More

Years of College

All Households With Less Than

4 Years of College

$\begin{array}{lll}57.7 & 66.5 & 76.3 \\ 78.0 & 83.6 & 88.4 \\ 41.4 & 52.9 & 66.6\end{array}$

49.7

71.0

39.0

73.7

39.6

54.9

59.7

62.4

53.6

49.7

44.0

43.2

33.5
60-62

35-39

$40-44$

50-54

$55-59$

60-62

Earnings (in \$000's)
$0-10$
$10-20$
20-30
30-40
40-50
50-75
$75+$

49.6

21.9

34.5

35.2

40.6

47.6

68.0
58.4

76.8

49.1

79.4

50.1

66.1

68.9

71.2

63.4

58.8

49.6

49.0

45.3

65.3

81.9

56.9

84.4

59.6

70.3

72.8

73.0

71.4

71.5

61.6

60.3

55.9

57.9

65.6

44.9

51.3

43.9

50.0

44.7

49.5

60.4

$\begin{array}{ll}59.5 & 67.8 \\ 73.9 & 81.4\end{array}$

Source: Authors' calculations. 
Table 4

Weighted Distribution of Wealth-Earnings Ratios

$\frac{\text { Age }}{\text { Percentile }} \frac{\begin{array}{c}\text { 25th } \\ \text { Percentile }\end{array}}{\text { 2001 SCF DATA }} \stackrel{\text { Median }}{\text { Percentile }} \stackrel{\begin{array}{c}\text { 75th } \\ \text { Percentile }\end{array}}{ }$

Narrow Wealth

$\begin{array}{lccccc}51-54 & 0.00 & 0.44 & 1.73 & 4.56 & 15.29 \\ 55-59 & -0.02 & 0.70 & 2.61 & 5.35 & 20.00 \\ 60-61 & 0.37 & 1.10 & 2.77 & 7.53 & 20.71\end{array}$

Intermediate Wealth

$\begin{array}{llllll}51-54 & 0.08 & 0.97 & 2.36 & 5.45 & 15.64 \\ 55-59 & 0.00 & 1.10 & 3.12 & 6.44 & 21.50 \\ 60-61 & 0.92 & 1.52 & 4.22 & 11.85 & 38.68\end{array}$

Broad Wealth

\begin{tabular}{lccccc}
$51-54$ & 0.08 & 1.37 & 2.89 & 6.18 & 17.02 \\
$55-59$ & 0.00 & 1.49 & 3.66 & 7.84 & 25.94 \\
$60-61$ & 1.10 & 1.90 & 5.17 & 14.13 & 70.11 \\
& \multicolumn{5}{c}{ SIMULATION } \\
& \multicolumn{5}{c}{} \\
$51-54$ & 0.42 & 1.37 & 2.30 & 3.50 & 5.75 \\
$55-59$ & 0.69 & 1.97 & 3.13 & 4.58 & 7.24 \\
$60-61$ & 1.08 & 2.50 & 3.85 & 5.46 & 8.33
\end{tabular}

Source: Authors' calculations. 
Table 5

Equity Holdings by Age Group and Quintile of Broad Wealth

Percent of Total

\begin{tabular}{|c|c|c|c|c|c|c|}
\hline Quintile & Lowest & Second & Middle & Fourth & Highest & All \\
\hline \multicolumn{7}{|c|}{ Age group } \\
\hline 25-34 & 0.13 & 0.44 & 1.11 & 1.82 & 2.66 & 6.17 \\
\hline $35-44$ & 0.14 & 0.52 & 1.73 & 4.42 & 14.98 & 21.75 \\
\hline $45-54$ & 0.01 & 0.31 & 0.76 & 3.54 & 40.89 & 45.58 \\
\hline $55-62$ & 0.00 & 0.09 & 0.22 & 1.91 & 24.35 & 26.53 \\
\hline All & 0.28 & 1.36 & 3.82 & 11.65 & 82.93 & 100.00 \\
\hline
\end{tabular}

Median Equity Holdings (Among Households with Equities)

Age group

25-34

$35-44$

2,900

6,500

28,000

55,000

228,000

10,000

$45-54$

3,000

6,000

28,500

65,500

205,000

32,000

55-62

1,200

8,500

13,000

60,000

315,100

61,500

All

2,000

14,000

13,000

59,500

259,500

80,700

2,700

6,500

20,000

62,000

260,000

34,000

Mean Equity Holdings (Among Households with Equities)

Age group

$\begin{array}{lllllll}25-34 & 3,916 & 11,504 & 35,634 & 96,502 & 535,575 & 48,906 \\ 35-44 & 7,475 & 12,095 & 36,680 & 79,647 & 367,319 & 106,141 \\ 45-54 & 3,282 & 14,128 & 22,400 & 73,346 & 592,320 & 257,770 \\ 55-62 & 2,693 & 20,654 & 17,450 & 82,987 & 742,971 & 357,705 \\ \text { All } & 5,001 & 12,636 & 30,621 & 80,270 & 561,820 & 171,893\end{array}$

Source: Authors' calculations. 
Table 6

Percent of SCF Households At or Above Simulated

Median Wealth-Earnings Ratios, 1983-2001

\begin{tabular}{|c|c|c|c|c|c|}
\hline Sample & Year & Age & $\begin{array}{l}\text { Narrow } \\
\text { Wealth }\end{array}$ & $\begin{array}{c}\text { Intermediate } \\
\text { Wealth }\end{array}$ & $\begin{array}{l}\text { Broad } \\
\text { Wealth }\end{array}$ \\
\hline
\end{tabular}

All Households

$\begin{array}{lllll}1983 & 25-62 & 42.9 & 61.7 & 71.0 \\ 1989 & 25-62 & 44.4 & 62.3 & 69.3 \\ 1992 & 25-62 & 47.0 & 59.7 & 66.4 \\ 1995 & 25-62 & 46.3 & 58.4 & 66.3 \\ 1998 & 25-62 & 49.5 & 60.8 & 66.7 \\ 2001 & 25-62 & 52.3 & 61.0 & 68.8\end{array}$

Younger Boomer (Born 1956-1964)

$1983 \quad 19-27$

$1989 \quad 25-33$

$1992 \quad 28-36$

$1995 \quad 31-39$

$1998 \quad 34-42$

$2001 \quad 37-45$
$----$

48.3

54.5

53.8

57.8

54.9
63.6

68.8

69.1

66.7

64.3

72.9

72.5

58.6

55.6

56.8

54.4
75.9

78.7

68.9

65.1

64.3

66.8

Source: Authors' calculations. 
Table 7

Weighted Distribution of Wealth-Earnings Ratios

(All Households, Age 51-61)

\begin{tabular}{|c|c|c|c|c|c|}
\hline Broad Wealth & $\begin{array}{c}\text { 5th } \\
\text { Percentile }\end{array}$ & $\begin{array}{c}25 \text { th } \\
\text { Percentile }\end{array}$ & Median & $\begin{array}{c}\text { 75th } \\
\text { Percentile }\end{array}$ & $\begin{array}{c}\text { 95th } \\
\text { Percentile }\end{array}$ \\
\hline 1992 & 0.07 & 1.81 & 3.53 & 7.57 & 23.97 \\
\hline 1995 & -0.03 & 0.45 & 1.30 & 3.07 & 11.17 \\
\hline 1998 & 0.00 & 1.81 & 3.44 & 7.15 & 21.97 \\
\hline 2001 & -0.04 & 0.61 & 1.82 & 4.22 & 14.23 \\
\hline
\end{tabular}

Source: Authors' calculations. 
Table 8

Percent of Households At or Above Median Simulated Wealth-Earnings Ratio

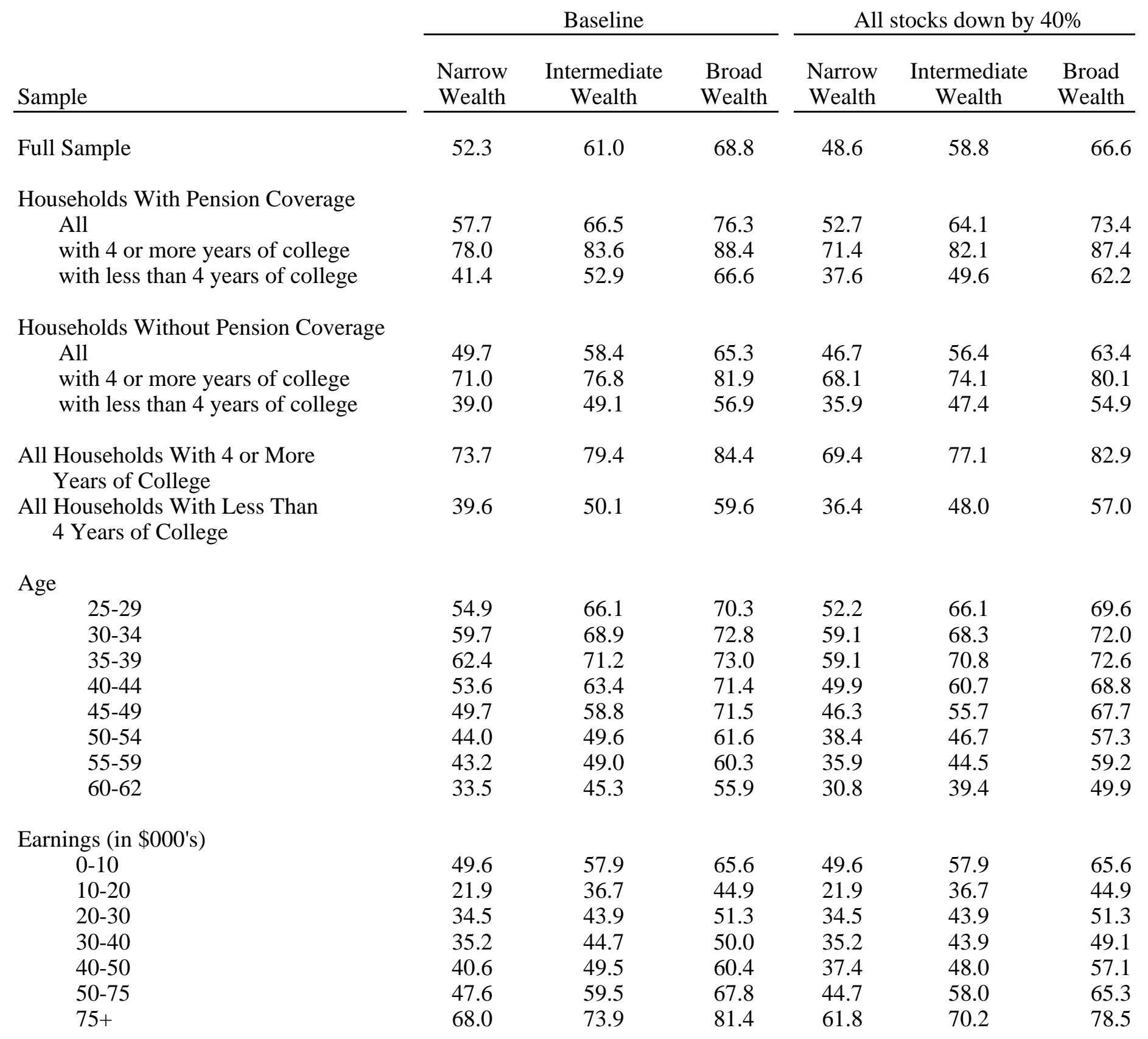

Source: Authors' calculations. 
Table 9

Sensitivity Analysis:

Percent of Households At or Above Simulated Wealth-Earnings Ratio

Case

$\underline{\text { Baseline }}$

$\underline{\text { Sensitivity Analysis }}$

40 Percent Decline in the Stock Market Exclude Business Wealth

20 Percent Increase in Target Ratios

10 Percent Lower Mortality Risk

\begin{tabular}{|c|c|c|}
\hline $\begin{array}{l}\text { Narrow } \\
\text { Wealth }\end{array}$ & $\begin{array}{c}\text { Intermediate } \\
\text { Wealth }\end{array}$ & $\begin{array}{l}\text { Broad } \\
\text { Wealth }\end{array}$ \\
\hline 52.3 & 61.0 & 68.8 \\
\hline
\end{tabular}

48.6

46.4

48.8

46.5
58.8

57.2

56.8

55.5
66.6

66.0

63.3

60.8

Source: Authors' calculations. 
Figure 1

Equities as a Fraction of Net Worth and GDP

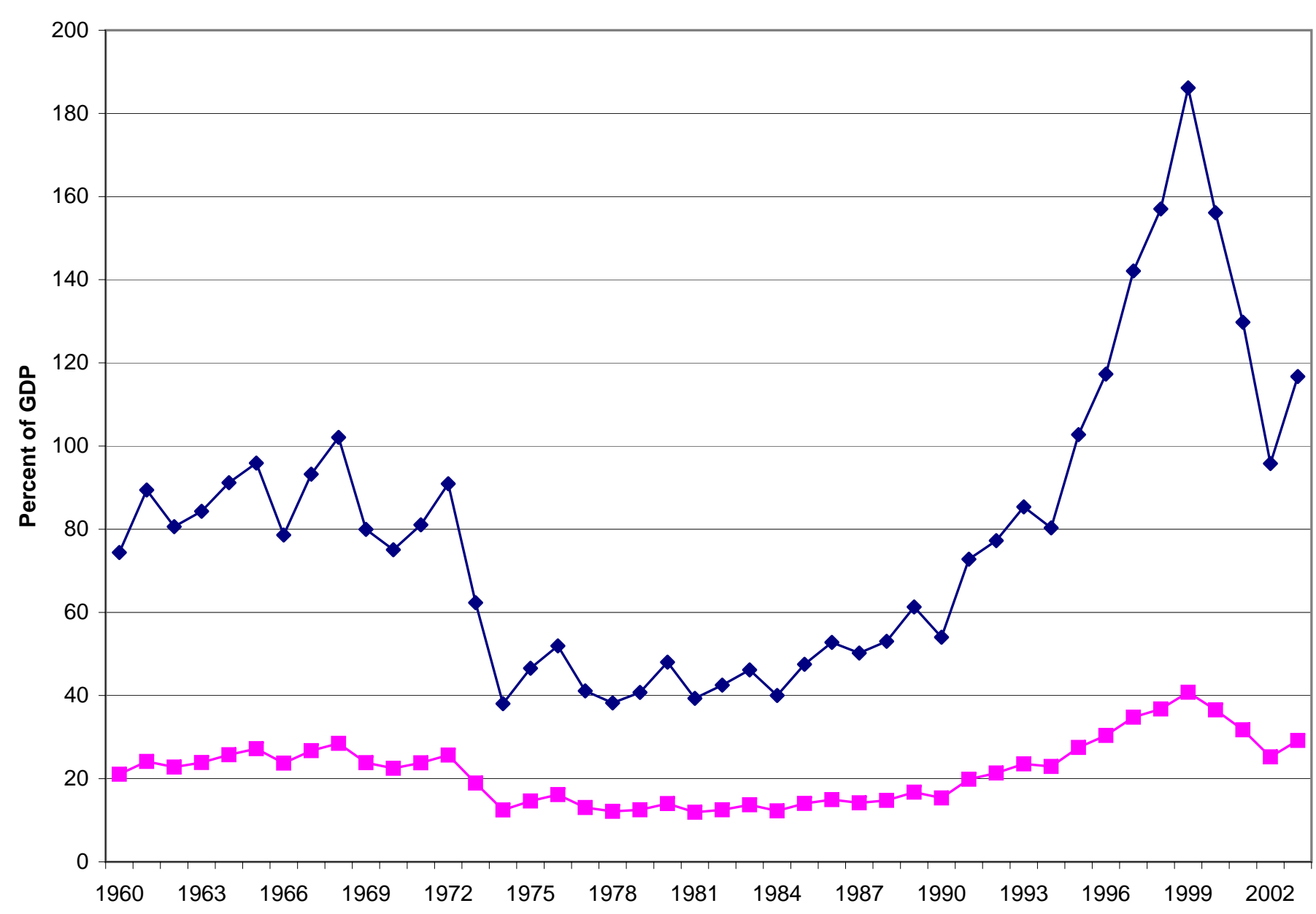

Aggregate net worth from Flow of Funds Accounts, Historical tables, Table B100, line 43.

Total value of equities from Flow of Funds Accounts, Historical Tables, Table B100e, line 6.

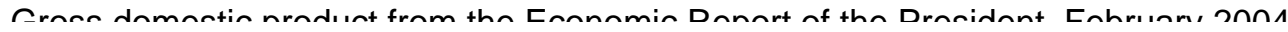


Appendix Table 1

Sample Sizes by Age, Education, and Pension Status $2001 \mathrm{SCF}$

\begin{tabular}{lcccccc}
\hline & \multicolumn{2}{c}{ Education $<16$ years } & & \multicolumn{2}{c}{ Education $\geq 16$ years } & \\
Age & No pension & Pension & & No pension & Pension & All \\
\hline $25-29$ & 86 & 10 & & 25 & 7 & 128 \\
$30-34$ & 85 & 26 & & 47 & 18 & 176 \\
$35-39$ & 101 & 31 & & 74 & 25 & 231 \\
$40-44$ & 123 & 49 & & 139 & 39 & 350 \\
$45-49$ & 103 & 43 & & 132 & 56 & 334 \\
$50-54$ & 77 & 41 & & 112 & 62 & 292 \\
$55-59$ & 64 & 22 & & 95 & 39 & 220 \\
$60-62$ & 33 & 9 & & 44 & 7 & 93 \\
All & 672 & 231 & & 668 & 253 & 1,824 \\
\hline
\end{tabular}

Source: Authors' calculations 


\section{RECENT WORKING PAPERS FROM THE}

\section{CENTER FOR RETIREMENT RESEARCH AT Boston COLLEGE}

Large, Small, International: Equity Portfolio Choices in a Large 401(k) Plan Julie Agnew and Pierluigi Balduzzi, May 2004

An Analysis of How Individuals React to Market Returns in One 401(k) Plan Julie Agnew, April 2004

The Effects of Health Insurance and Self-Insurance on Retirement Behavior

Eric French and John Bailey Jones, April 2004

Valuing Assets in Retirement Saving Accounts

James M. Poterba, April 2004

Lifetime Earnings, Social Security Benefits, and the Adequacy of Retirement Wealth Accumulation

Eric M. Engen, William G. Gale, and Cori Uccello, April 2004

The Effect of Social Security on Divorce and Remarriage Behavior Stacy Dickert-Conlin and Cristian Meghea, April 2004

Household Demand for Variable Annuities

Jeffrey R. Brown and James M. Poterba, March 2004

Lessons for an Aging Society: The Political Sustainability of Social Security Systems Vincenzo Galasso and Paola Profeta, March 2004

Choice and Other Determinants of Employee Contributions to Defined

Contribution Plans

Leslie E. Papke, March 2004

Linking Benefits to Marital Status: Race and Diminishing Access to Social Security Spouse and Widow Benefits in the U.S.

Madonna Harrington Meyer, Douglas A. Wolf, and Christine L. Himes, March 2004

Annuitization: Keeping Your Options Open

Irena Dushi and Anthony Webb, March 2004

Living Arrangements and Supplemental Security Income Receipt Among the Aged Melissa M. Favreault and Douglas A. Wolf, February 2004

All working papers are available on the Center for Retirement Research website

(http://www.bc.edu/crr) and can be requested by e-mail (crr@bc.edu) or phone (617-552-1762). 